\title{
Atropine-N-methylbromide の薬理作用
}

\author{
戸木田菊次中村直義 \\ (東邦大学医学部薬理学教室) \\ (昭和 32 年 9 月 18 日受付 [特])
}

\section{I.まえがき}

筆者の提唱せる鳩罥運動抑制法を用いてスクリーニングテストせる結果武田薬工竹内氏試製の二十数種の Alkaloide の中 Atropine-N-methyl bromide は最も優れた胃運動抑制効果を有する事が発見せられ, 其の臨床效 果に就いてもその優秀性を証明する多数の報告 (河野1)，川島2)，光井 ${ }^{32}$ 〕が次ざ次ざになされつつあり，等者も 多年に亘りその薬理作用に就いて実験せる結果 Atropine 固有の作用たる抗 ACh 作用の外に 同時に 4 級アンモ ニウム塩の作用たる神経節遮断作用の両作用を強力に保持する事を確認した。. Atropine-N-methyl (ANM 之略) については Lewis ${ }^{4)}$ 等が，神経節遮断作用が Atropine sulf. の15〜20倍強力である事を報告している. 此処䎲其 の結果を報告して諸賢の御批判を得たい。

\section{II. 䲧胃運動抑制効果}

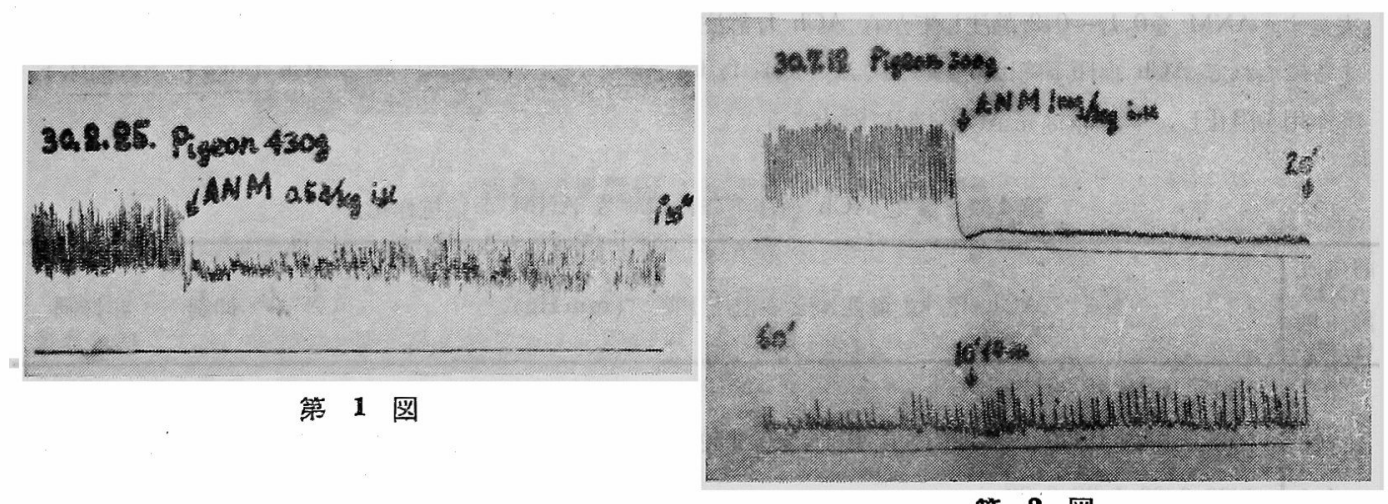

第 2 図

第 1 表. ANM 投与による鳩胃運動抑制持続時間.

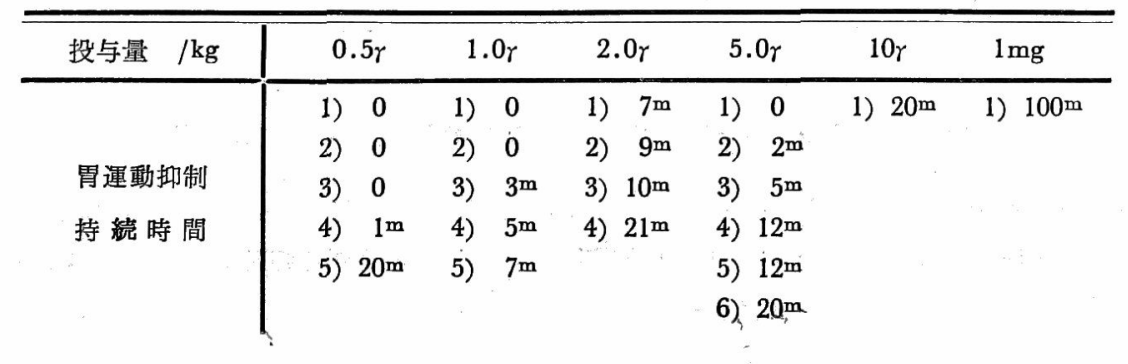




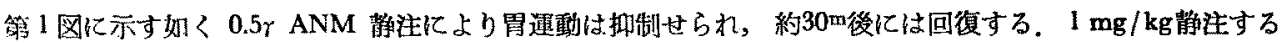

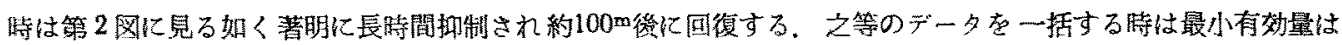

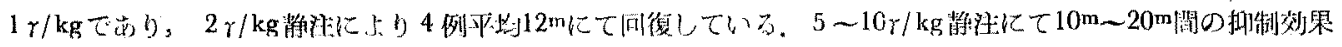
t示可.

\section{III. $\boldsymbol{カ}$ ス LDo}

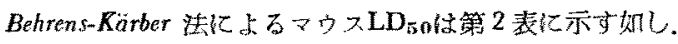

第 2 倩. ANM $の$ LD.

\begin{tabular}{|c|c|}
\hline 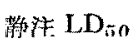 & $9.95 \mathrm{mg} / \mathrm{kg}$ \\
\hline 医下淮" " & $255 \mathrm{mg} / \mathrm{kg}$ \\
\hline 内眼 & $1640 \mathrm{mg} / \mathrm{kg}$ \\
\hline
\end{tabular}

\section{IV. マグヌス法抗 ACh 作用}

法の如くモルモット腸管によるマグスス法 る行つて $10^{-\top}$ ACh に括抗する ANM の淟度 は下表仁見る如く10-8でする。

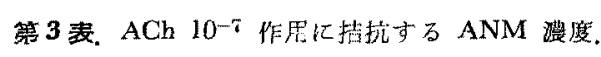

\begin{tabular}{|c|c|c|c|c|c|}
\hline ANM 溲度 & $10^{-6}$ & $10^{-\tau}$ & $10^{-8}$ & $10^{-9}$ & $10^{-10}$ \\
\hline ACb 作用把制例 & 5 & 5 & 4 & 2 & 0 \\
\hline 総数则 & 5 & 5 & 5 & 5 & 5 \\
\hline
\end{tabular}

\section{V. 抗 Pilocarpine 咬作用}

pilocarpine $1 \mathrm{mg} / \mathrm{kg}$ 静注による睡液作用に括抗するANM O量は0.01〜0.1 $/ \mathrm{kg}$ である〔首諭交ら第 7 表参 照].

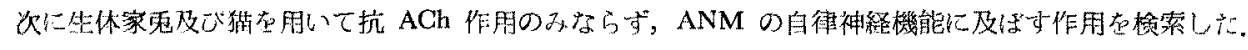

\section{VI. (I) 抗 ACh 作用}

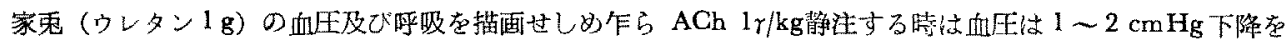

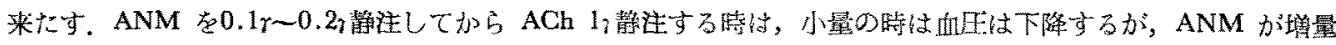

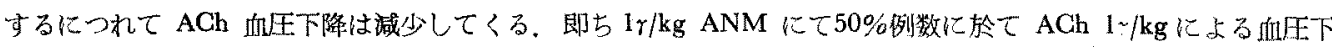

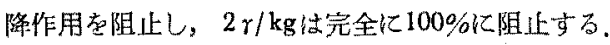

第4 表。家鬼 ACh 血圧下降飞対するANM の拮抗作用。

\begin{tabular}{|c|c|c|c|}
\hline 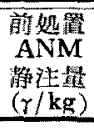 & $\mathrm{ACh} 1 \gamma / \mathrm{kg}$ 静注に上る血代下降 $(\mathrm{mmHg})$ & 的制到 & 非和制 \\
\hline 0.1 & $15 / 17 \quad 16 / 18 \quad 18 / 20 \quad 14 / 10$ & 0 & 3 \\
\hline 1.0 & $\begin{array}{lllllllllllllllllll}10 / 14 & 20 / 25 & 14 / 20 & 13 / 20 & 6 / 17 & 6 / 20 & 1 / 15 & 0 / 30 & 2 / 30 & 1 / 19 & 0 / 20 & 2 / 20 & 3 / 30 & 12 / 15 & 17 / 20\end{array}$ & 7 & $2: \stackrel{6}{\text { 多少抑制 }}$ \\
\hline 2.0 & $2 / 303 / 201 / 20 \quad 0 / 20$ & 4 & 0 \\
\hline 10.0 & 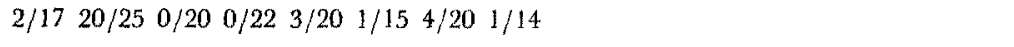 & 6 & 1 \\
\hline 100.0 & $1 / 25 \quad 0 / 20 \quad 1 / 20 \quad 2 / 18$ & 3 & 0 \\
\hline
\end{tabular}

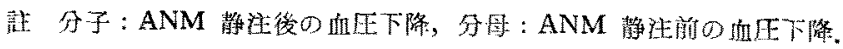

\section{VI. (2) Pilocarpine 血圧下降及び徐脈に対する祒抗作用}

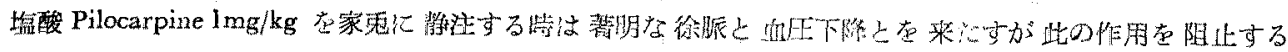

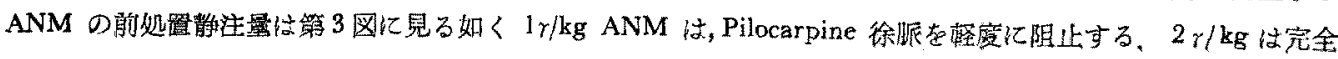
に阻止し，血左下降学之阻止するのが兒られる。 


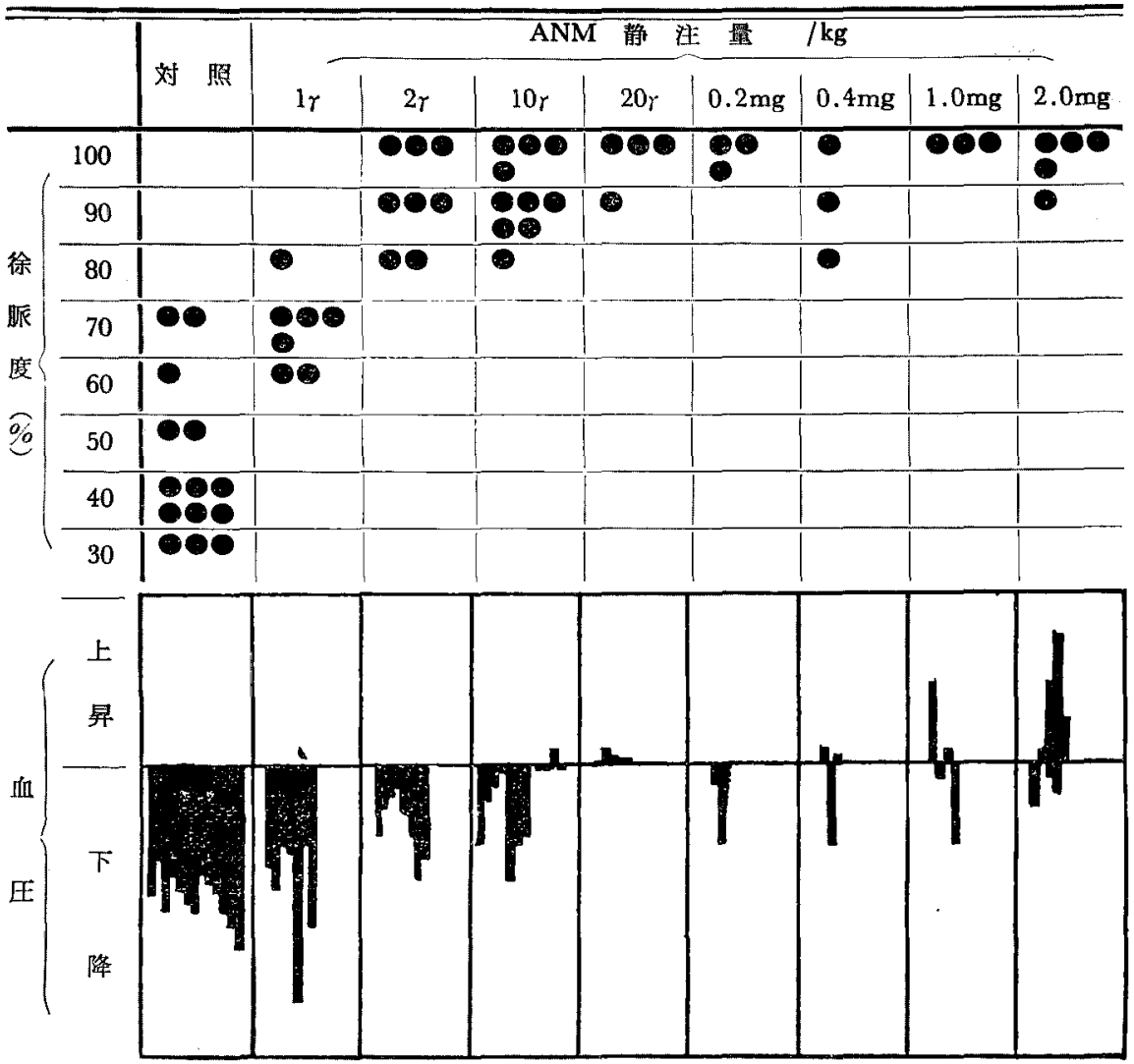

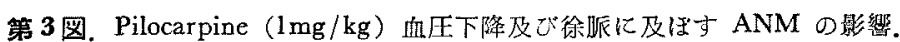

\section{VII．自律神経反射に及俧す ANM の作用}

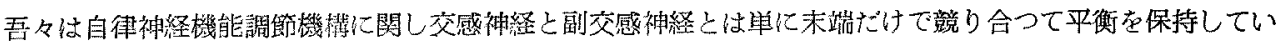

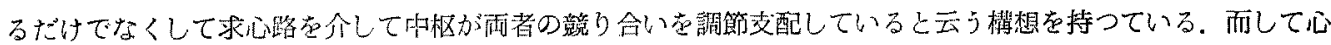

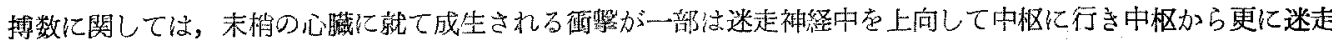

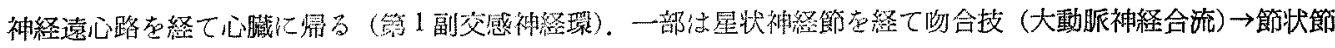

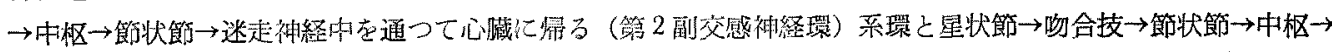

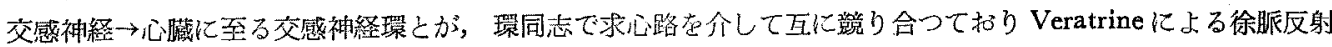
は第 1 副交感神経環, 即方 Vago-Vagal reflex そょつて発生するに反し Digitalis Adrenaline, Histamine 等の徐

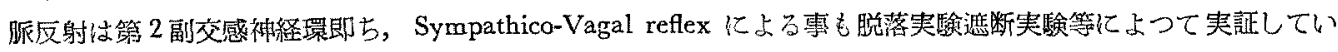
る. 而して此等の反射環の何れかの部位が遮断されれば反射は停止される結果が生れる. 此等の観点から ANM は心藏の反射機能に対して如何なる作用を有し且つ役制を持つかを解明せんと試みた。

a）Adr. 作用に及ぼす ANM の影響

ウレタン麻酔家乘 $(1 \mathrm{~g} / \mathrm{kg})$ 飞 Adr. $15 \mathrm{r} / \mathrm{kg}$ 静注する時は血圧は $4 \mathrm{~cm} \mathrm{Hg}$ 前後だけ上昇し 同時に著明な 30

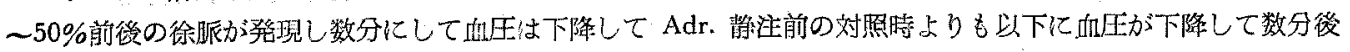

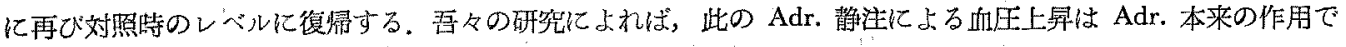

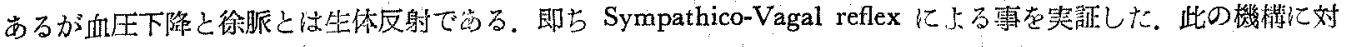

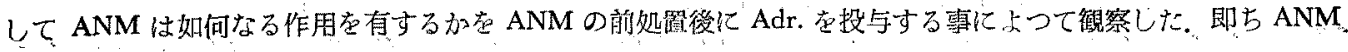



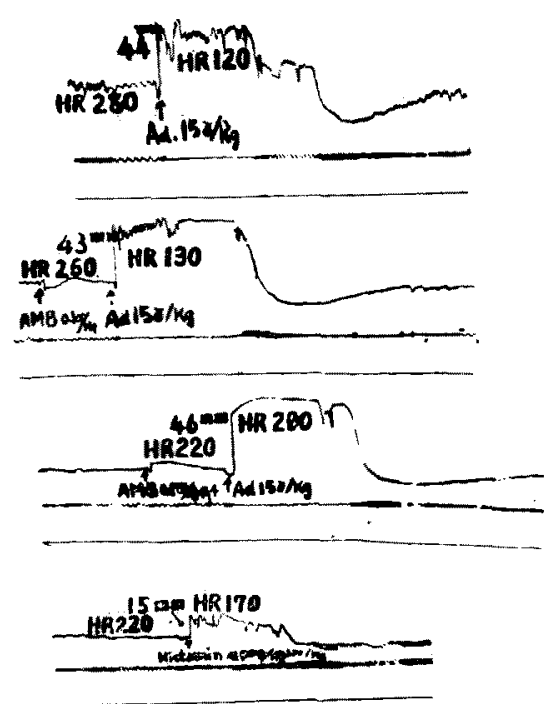

第 4图. ANM O家乘 Adrenaline 徐哌に 及借可影篦。

31.3 .2 家禹 $1.9 \mathrm{~kg}$

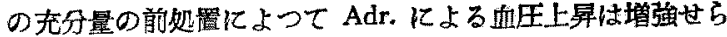

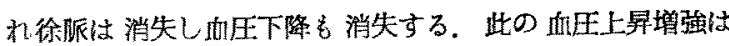
ANM $0.1 \sim 0.2 \mathrm{mg} / \mathrm{kg}$ 㥧より発現せられ自压下降の抑街作用

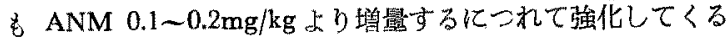
(第 5 表). Adr. 徐脈の消失は0.02mg前後上り消失しはじめ

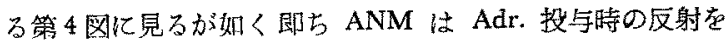
消失せしめる事が推定される。此の作用流抗 ACh 作用の ANM 2r比して0.1 mg と云う大量であるので作用点が異な る柔が推測される。

b) Histamine 血圧下隆及び徐眽に及ぼす钐響

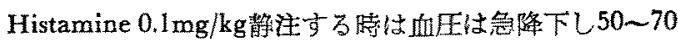
$\%$ 徐脈が発現する. ANM 0.1 0.6mg 前処罱静注後 Hista-

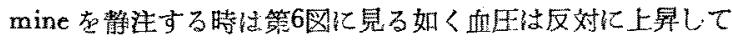
から更に下降し徐脈は発現しない，此の結果住家の星状神 経節を摘徐しだり或は再側 Vagusを切断したりした時の Histamine の作用と全く同しでする。

c) $\mathrm{BoCl}_{2}$ 徐眽に及ぼす影㸷

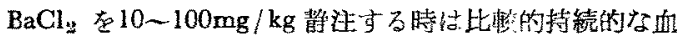
压上暑と同時に著朋な徐脈が発現される ANM の前処堺静

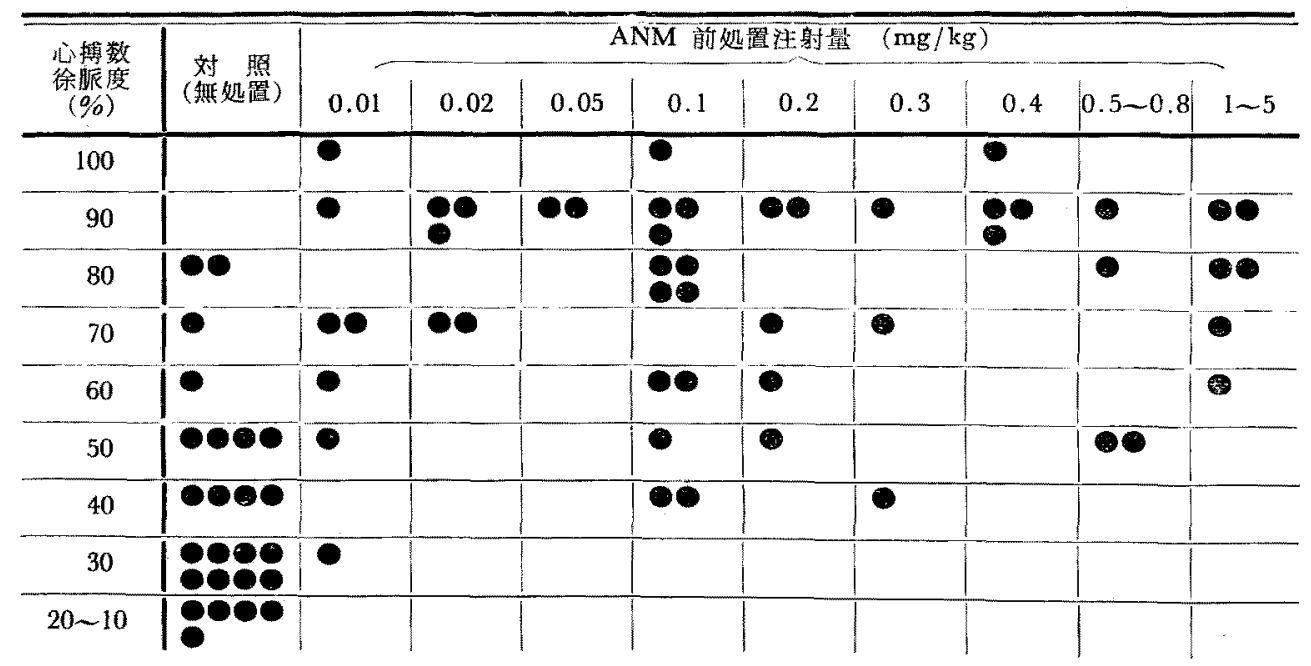

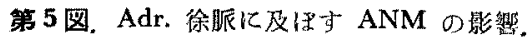

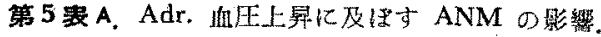

\begin{tabular}{|c|c|c|c|c|}
\hline \multirow{2}{*}{ 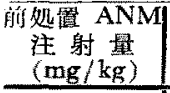 } & \multirow{2}{*}{ Adr. 血王上界 $\left(\mathrm{mmHg}^{\prime}\right)$} & \multicolumn{3}{|c|}{ 对照に比して } \\
\hline & & 促進 & 国等 & 䀙制 \\
\hline 0.02 以下 & 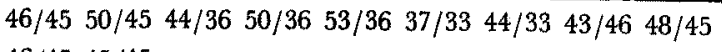 & 8 & 1 & $\mathbf{0}$ \\
\hline 0.05 & $46 / 45 \quad 45 / 45$ & 1 & 1 & 0 \\
\hline 0.1 & 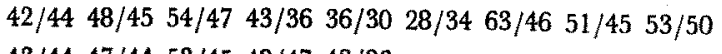 & 7 & 1 & 1 \\
\hline 0.2 & $43 / 44 \quad 47 / 44 \quad 53 / 45 \quad 48 / 47 \quad 43 / 36$ & 4 & 1 & 0 \\
\hline
\end{tabular}




\begin{tabular}{l|lllll}
0.3 & $45 / 4438 / 45$ & 0 & 1 & 1 \\
0.4 & $46 / 4442 / 44$ & 0 & 2 & 0 \\
0.5 & $46 / 4741 / 36$ & 1 & 1 & 0 \\
0.8 & $46 / 4547 / 47$ & 0 & 2 & 0 \\
1.0 & $46 / 4548 / 4748 / 4651 / 40$ & 2 & 2 & 0 \\
2.0 & $61 / 4541 / 4747 / 36$ & 2 & & 1 \\
4.0 & $52 / 47$ & 1 & & \\
7.0 & $54 / 47$ & 1 & & \\
計 & & 27 & 12 & 3
\end{tabular}

註 分子: ANM 注後，分母：ANM 注前.

第 5 表B，Adr，血压下降江及ぼす ANM の影腤。

\begin{tabular}{|c|c|c|c|}
\hline 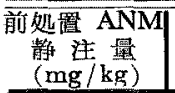 & Adr. 血 圧下 降 & \multicolumn{2}{|c|}{$\begin{array}{l}\text { 対照に比して } \\
\text { 抑制 非抑制 }\end{array}$} \\
\hline 0.02 以下 & $\begin{array}{lllllllll}17 / 16 & 12 / 29 & 20 / 29 & 18 / 24 & 11 / 24 & 7 / 14 & 9 / 14 & 12 / 20 & 10 / 15\end{array}$ & 8 & 1 \\
\hline 0.05 & $16 / 296 / 24$ & 2 & 0 \\
\hline 0.1 & $21 / 27 \quad 12 / 29 \quad 8 / 18 \quad 14 / 24 \quad 21 / 25 \quad 9 / 5 \quad 25 / 27 \quad 1 / 10 \quad 7 / 8$ & 5 & 4 \\
\hline 0.2 & $20 / 27 \quad 1 / 13 \quad 7 / 29 \quad 15 / 24$ & 4 & 0 \\
\hline 0.3 & $13 / 279 / 299 / 298 / 18$ & 4 & 0 \\
\hline 0.4 & $15 / 275 / 3$ & 1 & 1 \\
\hline 0.5 & $7 / 18 \quad 12 / 24$ & 2 & \\
\hline 0.6 & & & \\
\hline 0.7 & & & \\
\hline 0.8 & $7 / 18$ & 1 & \\
\hline 0.9 & & & \\
\hline 1.0 & $7 / 24$ & 1 & \\
\hline 2.0 & $10 / 297 / 183 / 24$ & 3 & \\
\hline 3.0 & & & \\
\hline 4.0 & $6 / 18$ & 1 & \\
\hline 7.0 & $3 / 18$ & 1 & \\
\hline 計 & & 33 & 6 \\
\hline
\end{tabular}

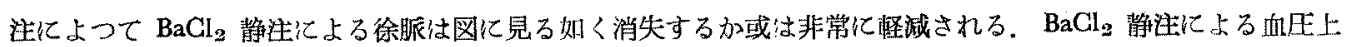

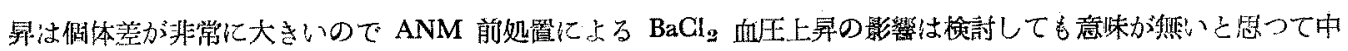
止したが Chlorpromazine の如く $\mathrm{BaCl}_{2}$ 而压上昇を阻止する事沈然かっつた。

d) Digitalis 徐胍に及ぼす影墕

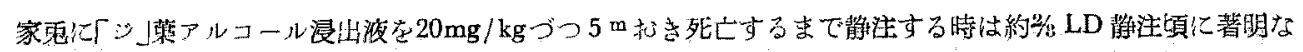

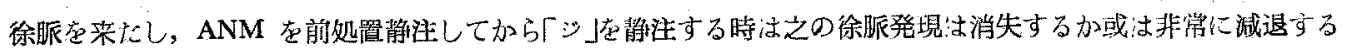
事は第 8 应に党る如くでかる。

e) Veratrine 徐胍に及ぼす影棃

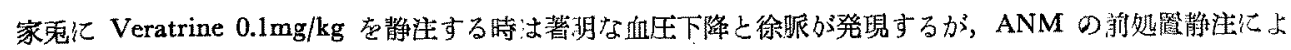
つて此の徐脈仗消失する. 第 9 図佂示可如くである。 


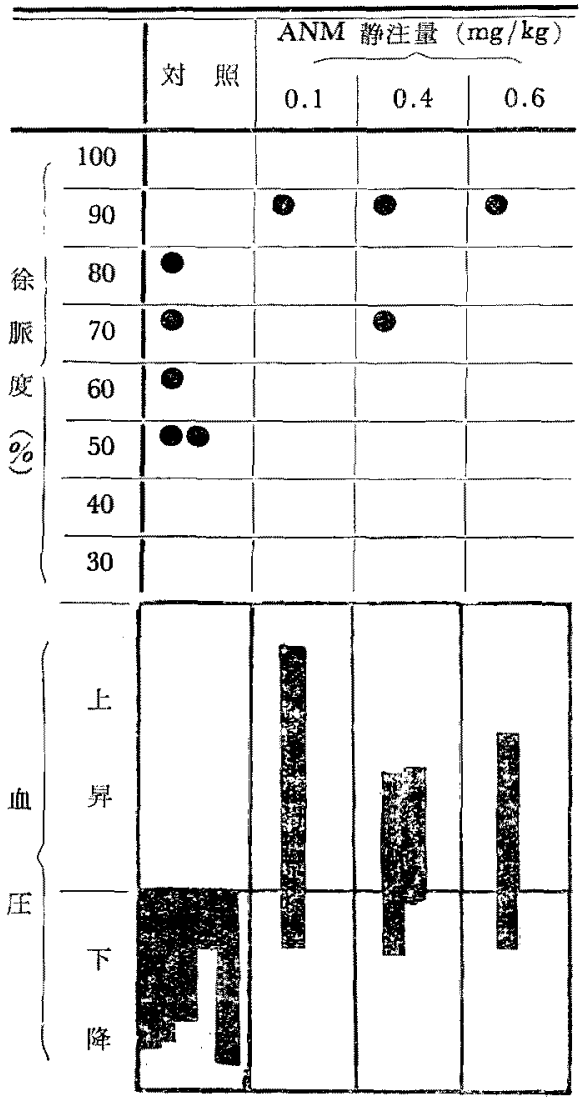

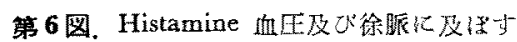
ANM の影愁.

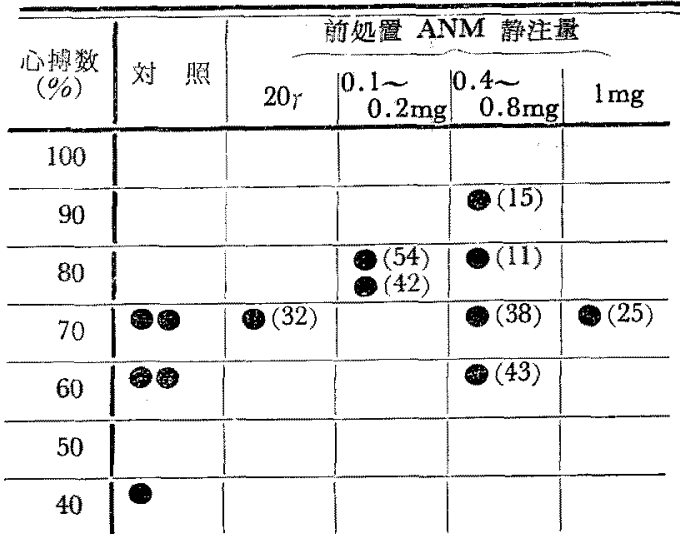

第 7 图， $\mathrm{BaCl}_{2}(10 \mathrm{mg} / \mathrm{kg})$ 徐脈に及ぽす ANM $\sigma$ 影溗。

註（）阳数字蚛血在上帠 $(\mathrm{mm})$.

\begin{tabular}{|c|c|c|c|c|c|c|c|}
\hline \multirow{2}{*}{$\begin{array}{c}\text { 氽脈舀 } \\
(\%)\end{array}$} & \multirow{2}{*}{ 奶 照 } & \multicolumn{4}{|c|}{ 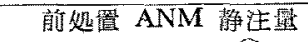 } & \multicolumn{2}{|c|}{$(\mathrm{mg} / \mathrm{kg})$} \\
\hline & & 0.1 & 0.2 & 0.4 & 1 & 2 & 5 \\
\hline 100 & & & & \% & 8 & & \\
\hline 90 & 60 & & & & & 0 & 2 \\
\hline 80 & 6 & . & & & 90 & 9 & \\
\hline 70 & 96 & & & & & (중 & \\
\hline 60 & & 0 & 0 & & & & \\
\hline 50 & & 6 & & & 8 & & \\
\hline 40 & 60 & & & & & & \\
\hline
\end{tabular}

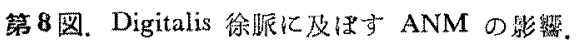

\section{VilI，猫による実験}

\section{a) 抗 $\mathrm{ACh}$ 作用}

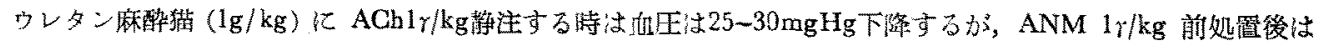

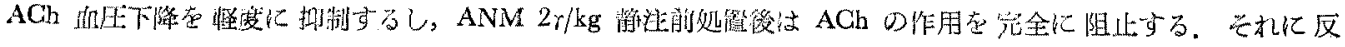

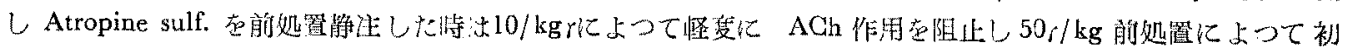
わて完全比るれを阻此する。

\section{b) 猫の神絽節遥断実験}

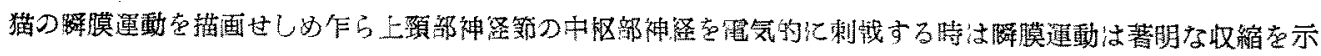

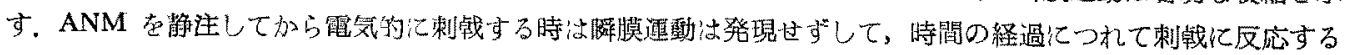

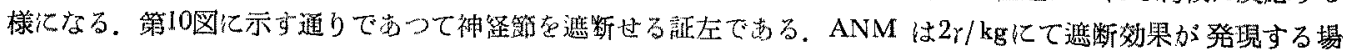

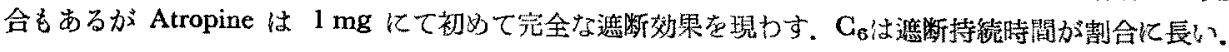




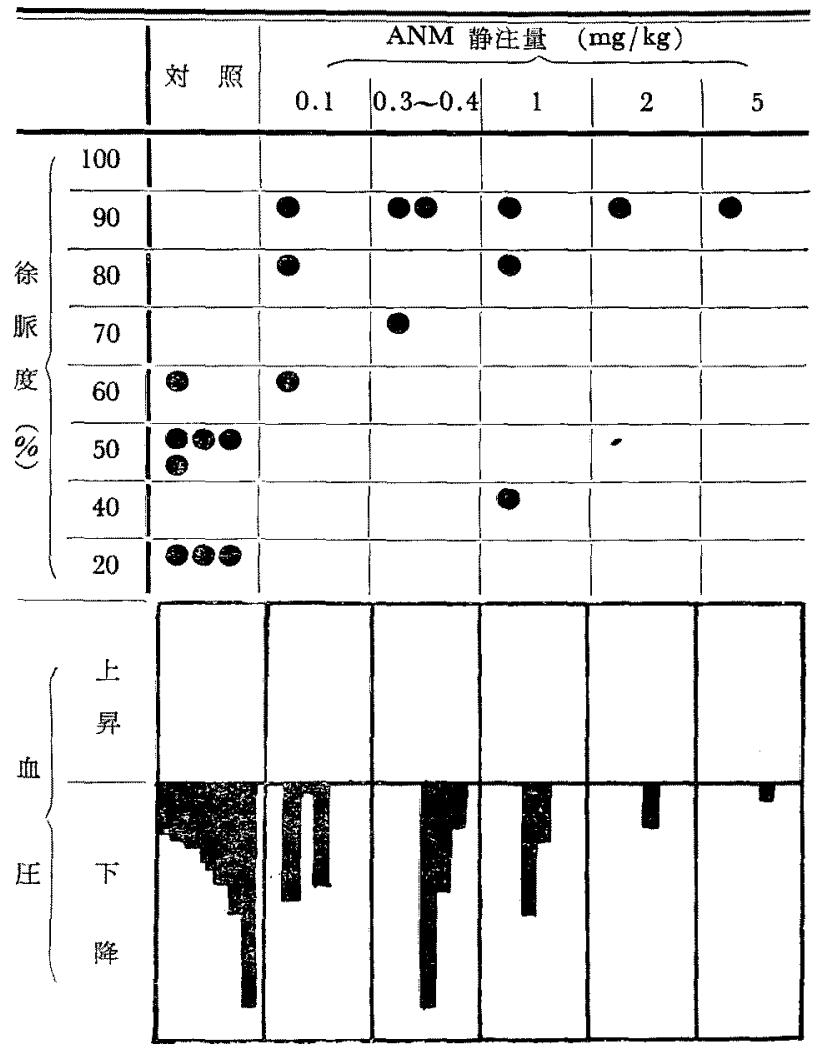

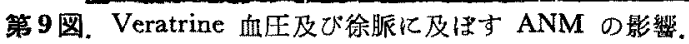

第6 致。

\begin{tabular}{|c|c|c|c|c|c|c|}
\hline \multirow{3}{*}{ No. } & \multicolumn{5}{|c|}{ ACh $1 r / \mathrm{kg}$ による血压下降 } & \\
\hline & \multirow{2}{*}{ 対照 (H.R.) } & \multicolumn{5}{|c|}{ ANM 前処置静注量 } \\
\hline & & $1 \gamma$ & $2 \gamma$ & $10 r$ & $50 r$ & $100 r$ \\
\hline 1 & -28 & -11 & -1 & & & \\
\hline 2 & $-25(21 / 18)$ & -27 & & -7 & & -3.0 \\
\hline \multirow[t]{2}{*}{3} & $-29(18 / 14)$ & -14 & 0 & & & \\
\hline & & \multicolumn{5}{|c|}{ Atropine sulfate } \\
\hline 4 & $-31(21 / 17)$ & -7 & & -10 & -1 & \\
\hline
\end{tabular}


$31-6-14$ 猫 $3.03 \mathrm{Kg}$ 9

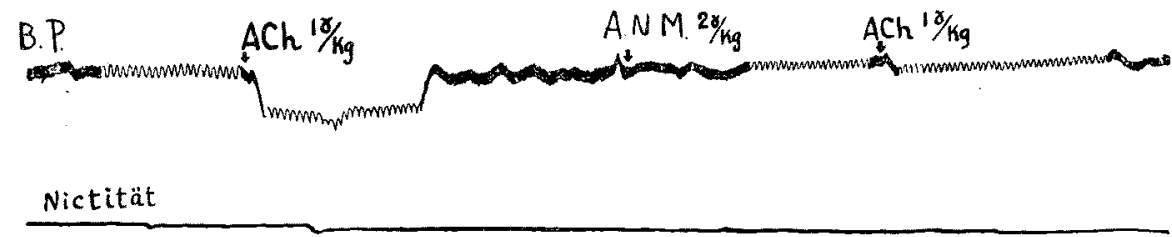

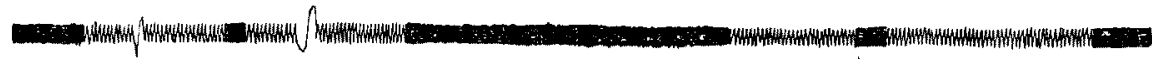

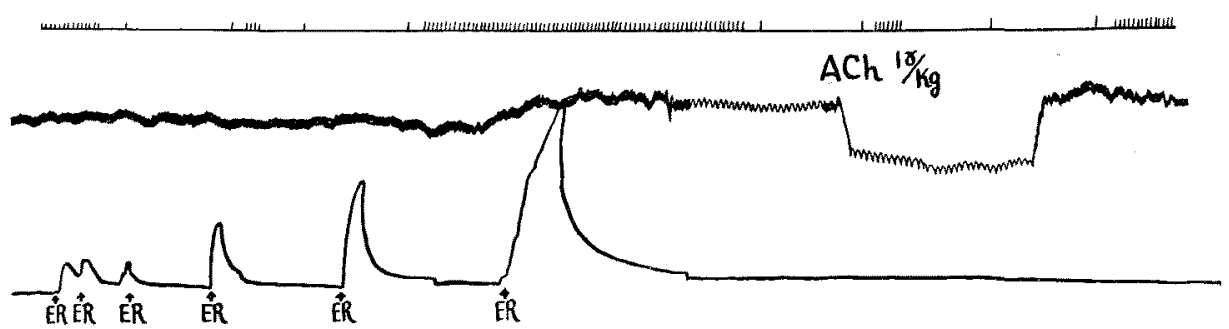

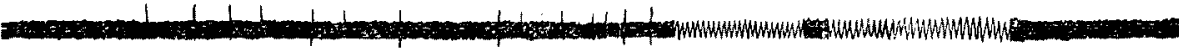

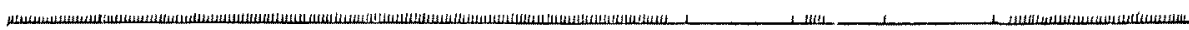

$$
\text { 第 } 10 \text { 図 }
$$

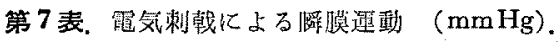

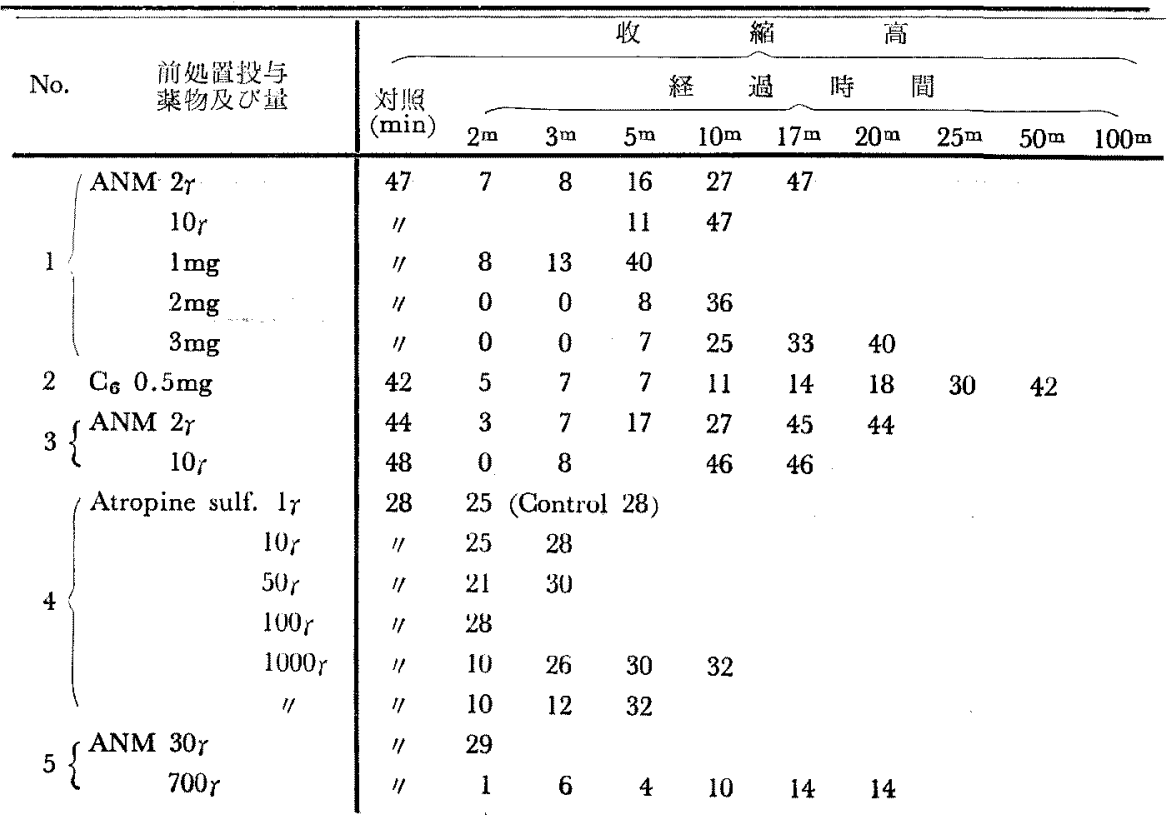




\section{IX. 稳括並びに検討}

今沦の奏験成頖を一括表記すれば，

\begin{tabular}{|c|c|c|c|c|c|c|}
\hline & 㥩 & 法 薬 & $\begin{array}{c}\text { ANM } \\
\text { 垠小有效量 }\end{array}$ & $\begin{array}{l}\text { Atropine } \\
\text { sulf. }\end{array}$ & TEA & $\begin{array}{l}\text { AN-benzyl } \\
\text { chloride }\end{array}$ \\
\hline \multirow{10}{*}{$\begin{array}{l}\text { モル } \\
\text { 生 }\end{array}$} & & 侅贯连動抑制 & $1 \sim 2 \gamma$ & 5 & 200 & 200 \\
\hline & 三ット腸管 & マダヌス法抗 $\mathrm{ACh}$ 法 & $0.01 \gamma / \mathrm{cc}$ & $0.1 \gamma / \mathrm{cc}$ & & \\
\hline & 家 & 抗 Pilocarpine 韮液作用 & $0.01 \sim 0.1 \gamma / \mathrm{kg}$ & $1 \gamma$ & & \\
\hline & $"$ & 抗 $\mathrm{ACh}(1 \gamma / \mathrm{kg})$ 衁圧作用 & $1 \sim 2 \gamma / \mathrm{kg}$ & $10 \sim 50 r$ & & \\
\hline & " & 抗 Pilocarpine 血玨下降徐眽 & $2 \gamma / \mathrm{kg}$ & $50 \mathrm{mg}$ & $50 \mathrm{mg}$ & \\
\hline & "l & 抗 Adr. $(15 r / \mathrm{kg})$ 徐眽 & $10 \sim 20 r / \mathrm{kg}$ & $1 \mathrm{mg}$ & $50 \mathrm{mg}$ & \\
\hline & $" \prime$ & 抗 Histamine $(0.1 \mathrm{mg}) / /$ & $\mathrm{lmg} / \mathrm{kg}$ & $1 \mathrm{mg}$ & $50 \mathrm{mg}$ & \\
\hline & $\prime \prime$ & 抗 $\mathrm{BaCl}_{2}(100 \mathrm{mg}) \quad$ " & $100 / / \mathrm{kg}$ & $1 \mathrm{mg}$ & $100 \mathrm{mg}$ & \\
\hline & $\prime \prime$ & 抗 Digitalis $(20 \mathrm{mg} \times 10)$ " & $1 \mathrm{mg} / \mathrm{kg}$ & & $100 \mathrm{mg}$ & \\
\hline & " & 抗 Veratrine $(0.1 \mathrm{mg}) "$ & $0.1 \mathrm{mg} / \mathrm{kg}$ & $\begin{array}{l}0.2 \mathrm{mg} \\
1.0\end{array}$ & $40 \mathrm{mg}$ & \\
\hline
\end{tabular}

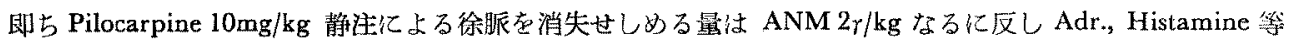

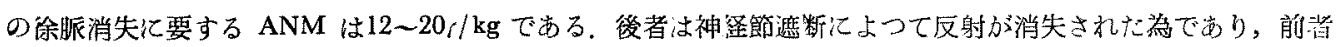

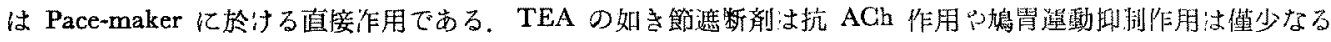

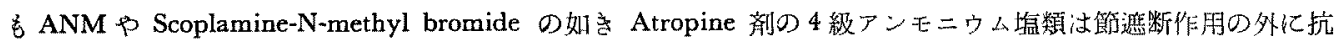
ACh 作用抗 Pilocarpine 作用を强力に併有している. 又, Atropine 類のNに付くアルキールの分子罢の大豆さに

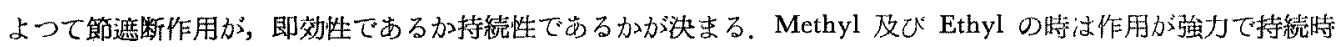

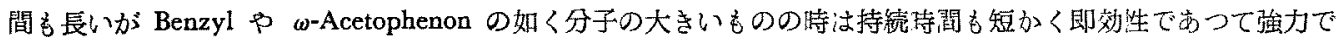

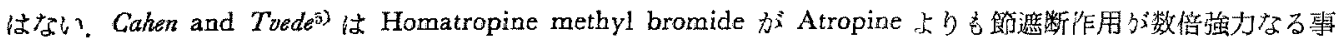
を報告しているが，余の実験てよればNにBenzyl-chloride の付いた Homatropine (竹内㫼製) 仙 Atropin sulf. よりも作用が非常に弱い.

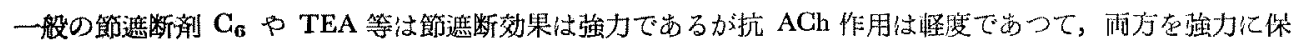
持するちのは ANM の類以外にはをれを見出し得ない.

\section{女献}

1)河野，小沢：第42回日本消化器病学会総会で発表。

2)川島, 弪山: 同上.

3) 吉井, 平野 : 同上.

4) Lewis, D. Fink \& Peter Cervoni : J. Pharmacol. 109, 372 (1953).

5) 戸木田：日滦理誌 53, 1119 (1957).

6) Cahen \& Tvede : J. Pharmacol. 106, 166 (1952). 